\title{
Problems of Accounting and Tax Base Formation on Income Tax
}

\author{
Mironova O.A. ${ }^{a}$ \\ Hanafeev A.F.b1 \\ ab Volga State Technical University, Yoshkar-Ola, 424000, Russia \\ 'Email:nkc.yola@gmail.com
}

\section{Doi:10.5901/mjss.2014.v5n12p183}

\begin{abstract}
Disclosed questions requiring development of methodological approaches to accounting and formation of tax base for corporate income tax. Authors' position formulated to solve the problems of the tax base reduction and transferring income of organizations which are involved in the transaction as interdependent entity.
\end{abstract}

Keywords: the concept of profit, tax profit, account of the tax base, the transfer of profits, control of transactions, interdependent persons.

\section{Introduction}

With the development of the tax system in the national economy of countries using market mechanisms of control, raises questions about the difference between profit indicators, reflected in accounting and tax reporting. In business entities that form these types of reports, becomes necessary internal control over the differences in terms of profit, as well as the formation of the tax base for income tax purposes. So far Russian regulations and accounting standards do not contain effective tools for accurate calculation of profit indicators in different reporting formats. Issues of selecting items in accounting and tax policy also require its development, as well as ways to monitor and evaluate the accounting and tax profits are reported, including by controlling tax authorities [1].

\section{Theory}

The theoretical substantiation of transformation indicators accounting profit in depending on its assessment methods based on economists fundamental research and reflected in the International Financial Reporting Standards. Most of the research on accounting and income taxation is based on the position that the concept of accounting profit does not has a sufficiently clear formulation, and as a consequence, there is no theoretical basis for the calculation of accounting profit and it's reflection in the financial statements. Different orientation of business objectives requires different estimates of profits, including profits reflected in the financial statements.

The main purpose of income reporting comes down to providing information to interested users: in the net profit and its assessments is interested the company's management in estimates of general purpose - external users. In this regard, we can talk about different concepts of income, the most significant of which in Russia and abroad are recognized:

- The concept of accounting profit (or syntactic concept of profit);

- The semantic conception of profit;

- $\quad$ Pragmatic concept of profit;

- The concept of market profit.

Characteristics of concepts contained in different sources of English and American accounting literature systematized in Table 1. 
Table 1: Characteristics of the most important income concepts

\begin{tabular}{|c|c|c|}
\hline $\begin{array}{l}\text { The Concept of } \\
\text { Income }\end{array}$ & The Purpose of Determine the Earnings & Approaches to the Income Determination \\
\hline $\begin{array}{l}\text { 1. The concept of } \\
\text { accounting profit } \\
\text { or syntactic } \\
\text { concept of profit }\end{array}$ & $\begin{array}{l}\text { Accounting profit is a means of evaluating the company, } \\
\text { mainly used for forecasting cash flows. Indicators of the } \\
\text { accounting profit relevant to decision models by external } \\
\text { users, who need to understand the meaning of } \\
\text { accounting profit should be considered by the method } \\
\text { and algorithm of its calculation. }\end{array}$ & $\begin{array}{l}\text { Approaches to the calculation of accounting profit: } \\
\text { a) operational approach. Is the most common and is accomplished } \\
\text { by recording the corresponding estimates of assets and accounts } \\
\text { payable in the accounts, provided that these changes are the result } \\
\text { of operations (transactions). Should distinguish between internal } \\
\text { and external operations that are reflected in different ways on the } \\
\text { change in accounting estimates; } \\
\text { b) extended operating approach allows you to shape and reflect the } \\
\text { reported profit activities of the company. }\end{array}$ \\
\hline $\begin{array}{l}\text { 2. The semantic } \\
\text { conception of } \\
\text { profit }\end{array}$ & $\begin{array}{l}\text { Expense is recognized in the two economic purposes: } \\
\text { first, welfare changes of owners and employees of the } \\
\text { company, and secondly, profit maximization under } \\
\text { certain conditions, depending on the market structure, } \\
\text { demand and production, cost and pricing policies. }\end{array}$ & $\begin{array}{l}\text { Approaches to the calculation of economic profit: } \\
\text { a) the determination of profit as an indicator of efficiency, affects } \\
\text { the current dividend rates, the use of capital. Definition of efficiency } \\
\text { must be balanced with the purpose of business - profit } \\
\text { maximization or providing acceptable levels of return on invested } \\
\text { capital. } \\
\text { b) determining the differences of economic accounting profits. } \\
\text { c) determination of multivariate profit (accounting income in relation } \\
\text { to the economic profit of the alleged conditions of certainty) }\end{array}$ \\
\hline $\begin{array}{l}\text { 3. Pragmatic } \\
\text { concept of profit }\end{array}$ & $\begin{array}{l}\text { Gains related to the processes of decision-making by } \\
\text { investors and creditors }\end{array}$ & $\begin{array}{l}\text { Approaches to income forecasting: } \\
\text { a) profit regarded as the basis of forecasting. The set of indicators } \\
\text { is determined on the assumption that between reported earnings } \\
\text { and cash flow there is a relationship. Projected earnings are used } \\
\text { for making investment decisions and risk assessment; } \\
\text { b) income is considered as the basis for management decision. } \\
\text { Moreover, the impact of decisions on future developments are } \\
\text { considered. }\end{array}$ \\
\hline $\begin{array}{l}\text { 4. The concept of } \\
\text { market profit }\end{array}$ & $\begin{array}{l}\text { Net profit of companies regarded as the basis for the } \\
\text { projections in the securities markets. }\end{array}$ & $\begin{array}{l}\text { Building a model of expected net profit requires an understanding } \\
\text { of the behavior of income in a time interval. } \\
\text { There are variations of market-based approaches to the definition } \\
\text { of income, for example, to determine the terms of the agreements } \\
\text { of contracts; for determining the efficiency of use of resources; for } \\
\text { the overall change in ownership of the company; etc. }\end{array}$ \\
\hline
\end{tabular}

All characterized concepts were recognized as separate areas of the theory and are interpreted differently by the authors in the scientific literature. Indisputable is only the fact that the concept taken separately can not be the basis for the management of profit on the basis formed in the accounting and taxation information. The most commonly used an integrated approach because for profit management is necessary not only determine its value in the balance sheet and calculate the income tax for a particular reporting period, but also to determine the forecast values of future tax burden based on the current practice of profit taxation.

\section{Results}

With the introduction of Chapter 25 "Corporate Income Tax" of the Tax Code of Russian Federation approach to determining the profits of Russian organizations for tax purposes is highlighted as an independent, non-income accounting definitions. Note that in the method of calculating the tax base of income tax features are present, which lead to differences in tax and accounting indicators. These features are associated, first, with the calculation of expenditure undertaken to determine the taxable base for the closed list; secondly, with determination of costs charged by calculation to work in progress, finished goods and the remains shipped products; thirdly, with the release of as separate entities accounting for deferred tax assets and deferred tax liabilities.

In Russian accounting list of costs taken for calculation of profit is determined by the Statement of Accounting Practice (SAP) 10/99 "Expenses" and accounting policy. In comparison with the list of costs taken for computation of taxable profit, balance list is wider. Existing differences in practice sometimes lead to paradoxical situations where, for example, on the same balance sheet date in the tax accounting profit is defined, and based on accounting data - loss [25].

Methodological approaches to the definition of accounting and tax profit, the existing differences in order of their 
calculation became the basis for the recognition in the Russian accounting of tax profit concept. Much attention is paid to the account of permanent and temporary differences, regulated by the Statement of Accounting Practice (SAP) 18/02 "Accounting of calculations on organization's income tax". Income and expenses forming the accounting profit for the accounting period and not recognized for determining the tax base for income tax recognized permanent differences, as well as income and expenses taken into account when determining the tax base for income tax, but are not recognized for accounting purposes. The emergence of permanent differences entails the necessity of recognition tax liabilities (or assets of tax), which are determined by multiplying the constant differences arising during the reporting period on the income tax rate at the balance sheet date. Temporary differences in the formation of taxable profits entail the formation of deferred income tax, which affects the amount of tax payable to the budget in subsequent periods.

Tax conception of forming income for the Russian organizations is significant in the sense that the indicators related to the calculation of the tax base of income tax, due to stringent requirements for their definition and require supervision by the accountants, leading tax accounting and implementing calculation of income tax.

Management of accounting and tax profit differences appearing between them requires, in turn, create a "defense mechanism" in the form of reserves. Currently the reservation of balance sheet items used in Russian accounting extreme caution. Meanwhile, the importance of this method is always emphasized by Russian scientists. Thus, in the first half of XX century Y.M. Halperin described balance backup method in the manner by which the current account can be pre-calculate losses, the real value of which turns out only at the time of drawing up of balance. Among the characteristics of redundancy, as a method, which draws the attention of Y.V. Sokolov was isolated response: "backup as a consequence of identification", implying recognition of income and expenses in specific periods. Following this characterization, we propose to identify two groups of reserves [6, 9]:

- Provisions for reflecting losses occurring as a result for payment of income tax in the case when in accounting the financial result of organization displayed as a loss and in the tax accounting formed a certain amount of taxable income, and tax calculus;

- Reserves for the regulation of financial results arising in connection with operations on write off of deferred tax assets and repayment of deferred tax liabilities in different time periods.

Application of these provisions in practice will reduce accounting risks and guide the amount of provisions for repayment of arising losses in accounting. In addition, will be further development of Russian accounting system reserves. For users of the accounting and financial statements will need rationale for provisioning and organization of control over their use. In the content of balance sheet items is necessary to allocate new ones reflecting the amount of unused reserves at the reporting date. In accounting policies will need the inclusion of provisions on the formation one or another reserve, and in the work plan accounts - selection of special accounts for their accounting.

From the standpoint of controlling authorities reporting information from the organization which is an subject to income taxes, will be a source for the analysis of the financial situation in which, regardless of financial results obtained in the accounting, the taxpayer will be able to repay their obligations to the budget, by paying assessed amount of income tax timely.

In large organizations, having in its composition subsidiaries, which use in the formation of financial result transfer pricing, the proposed reserve system will identify unwanted The dynamics of formation and use reserves to pay accounting losses arising from different time periods, align transfer prices established with different ranges for individual subsidiaries.

Collation of information about using transfer pricing in the formation of the accounting income and information on using transfer pricing in the taxation will reveal new mechanisms of tax risk management. This is especially true with the position the tax legislation brought into use in 2011, relating to controlled transactions carried out between related parties ("the parent company - subsidiary", "fellow subsidiaries", etc.) [7, 10-11].

Establishment of special commercial and financial conditions in transactions between related parties distinguishes them from transactions if they occurred between conventional independent companies. This difference usually lies in the pursuit of associates reduce the tax base and/or realize the transfer of income from one taxpayer to another. In international practice, if such a transaction between related parties performed in order to transfer income to a company located in a tax jurisdiction with a significant privileges to income tax, then the problem is regarded as tax evasion. In world practice, this problem is called "reducing of the tax base and transferring income". The presence and extent of reduction of the tax base and transfer income in selected OECD countries surprising analysts of tax administration because receipts from corporate income taxes are a significant part of the revenue of the state budget. As a percentage of the average value of corporate income tax in 2011 in OECD countries amounted to $3 \%$ of GDP. [3]

At the moment the problem of reducing taxable base and transferring income to is solved through the continuous review of preferential regimes in the countries - participants of the OECD, especially those regimes that using global 
mobile technology, such as the provision of services based on the availability of intangible assets. Experts recognize this practice as malicious, based on the provisions of the OECD report "malicious competition in the field of taxation: a new global problem" (1997).

Russian tax administration, in turn, is also developing a system of measures on tax issues of related parties and transactions carried out between them. Particular attention is paid to transactions which result in reduction of the tax base of income tax for those participants who have registered and paid taxes in the territories of non-offshore or special economic zones. In this regard, it should highlight the main position, the development of which should be devoted to further development of scientists and practitioners:

- $\quad$ to increase transparency of taxation issues of major Russian companies and their subsidiaries, participating as related parties in certain transactions, subject to the further development of the system of inter-agency and inter-ethnic (with other tax jurisdictions) the exchange of information. This will create a database, including data on the malicious practice of taxation and harmful tax competition. Monitoring of such information can perform the Federal Tax Service with Inter-regional tax inspections on the major taxpayers in the formation and analysis of data on controlled transactions;

- in order to strengthen the control the correct application of transfer pricing in tax practice should expand the range of activities carried out by the tax administration, including control over the activities of taxpayers that expose their business to structural adjustment. Restructuring issues are always associated with the redistribution of risk and changing of methodological instruments of profit generation. If the main tool performs the transfer price, then required more rigid approaches to the use of methods for determining the transactional profit and attribution of profits to the parent company (or the company responsible for the implementation of transactions between related parties);

- in order to limit the ability to apply aggressive tax planning schemes, we need to strengthen controls in the operations on: the transfer of debt from the purchaser of the main assets of operating companies; evasion of VAT tax at source of payment; hedges after tax; etc. Special areas of tax risk in this regard should be allocated corporate and banking losses incurred as a result of aggressive tax planning schemes. For such taxpayers is necessary to clarify the existing recommendations for disclosure in the financial statements, which, in turn, could analyze analysts tax administrations.

\section{Conclusions}

Thus, the formation of the tax base for income tax by Russian companies has become an important issue in terms of reducing tax risk and tax management, especially in the case of transactions between related parties and reducing of the tax base and income transfer from one company to another. In this regard, the authors formulated provisions whose application in the Russian practice of accounting, taxation and tax administration will prevent unwanted tax consequences and reduce tax risks.

\section{References}

Eldon S. Hendriksen, Michael F. van Breda. Accounting theory. Fifth Edition. IRWIN. Homewood, IL 60430. Boston, MA 02116.

Safiullin L.N., Gafurov I.R., Shaidullin R.N., Safiullin N.Z. Socio-economic development of the region and its historical and cultural heritage. Life Science Journal 2014; 11(6s): 400-404.

Wyrwich, M. Regional Entrepreneurial Heritage in a Socialist and a Postsocialist Economy // Economic Geography 88 (4), 2012. pp. $423-445$.

Belverd E. Needles, Jr., Henry R. Anderson, James C. Caldwell. Principles of accounting. Houghton Miffin Company. Boston.

OECD (2013), Addressing Base Erosion and Profit Shifting (Russian version), OECD Publishing. http://dx.doi.org/10.1787/9789264201262-ru

Kramin M.V., Safiullin L.N., Kramin T.V., Timiryasova A.V. Drivers of economic growth and investment attractiveness of Russian regions. Life Science Journal 2014; 11(6s): 526 - 530.

Gauselmann, A., Marek, P. Regional determinants of MNE's location choice in post-transition economies // Empirica39 (4) , 2012. pp. 487-511

Panasyuk M.V., Pudovik E.M., Sabirova M.E. Problems of labor market of modern Russia in conditions of stable economic growth. Life Science Journal 2014; 11(6s): 487 - 489.

Validova A.F. Inflation targeting in developing countries: perspectives for Russia. Life Science Journal 2014; 11(6s): 494 - 498.

Huning, S., Naumann, M., Bens, O., Hüttl, R.F. Transformations of modern infrastructure planning in rural regions: The case of water infrastructures in Brandenburg, Germany // European Planning Studies19 (8) , 2011. pp. 1499-1516

Hajrullina A.D., Romadanova O.A. Technique of measurement of value of the human capital as intangible asset of corporation. Life Science Journal 2014; 11(6s): $518-521$. 